\title{
Impulsivity is relevant for trauma exposure and PTSD symptoms in a non-clinical population
}

\author{
Liana R. Netto ${ }^{\mathrm{a}, *}$, Juliana L. Pereira ${ }^{\mathrm{a}, \mathrm{c}}$, José F. Nogueira ${ }^{\mathrm{a}}$, Patrícia Cavalcanti-Ribeiro ${ }^{\mathrm{a}, \mathrm{f}}$, \\ Rejane Conceição Santana ${ }^{\mathrm{a}}$, Carlos A. Teles ${ }^{\mathrm{c}, \mathrm{e}}$, Karestan C. Koenen ${ }^{\mathrm{d}}$, The Trauma \\ and Anxiety Disorders Study Group - UFBA ${ }^{a}$, Lucas C. Quarantini a,b \\ a Programa de Pós-graduação em Medicina e Saúde (PPgMS), Faculdade de Medicina da Bahia, Universidade Federal da Bahia, Salvador, Bahia, Brazil \\ ${ }^{\mathrm{b}}$ Departamento de Neurociências e Saúde Mental, Faculdade de Medicina da Bahia, Universidade Federal da Bahia, Salvador, Brazil \\ ${ }^{\mathrm{C}}$ Universidade Estadual de Feira de Santana, Feira de Santana, Bahia, Brazil \\ d Department of Epidemiology, Mailman School of Public Health Columbia University, New York, NY, United States \\ e Centro de Pesquisas Gonçalo Moniz/Fiocruz, Salvador, Bahia, Brazil \\ ${ }^{\mathrm{f}}$ Escola Multicampi de Ciências Médicas, Universidade Federal do Rio Grande do Norte, Brazil
}

\section{A R T I C L E I N F O}

\section{Available online 15 March 2016}

\section{Keywords:}

Posttraumatic stress disorder

Traumatic experiences

Impulsiveness

BIS-11

Young adults

\begin{abstract}
A B S T R A C T
Impulsivity is a relevant construct for explaining both normal individual differences in personality and more extreme personality disorder, and is often investigated within clinical populations. This study aims to explore the college students' impulsivity patterns and to investigate the association across levels of impulsivity with trauma exposure and PTSD development in a non-clinical population. A one-phase census survey of seven college institutions assessed 2213 students in three metropolitan regions of Northeastern Brazil. All subjects anonymously completed a self-applied protocol consisting of: a sociodemographic questionnaire, Trauma History Questionnaire (THQ), PTSD Checklist (PCL-C), and Barratt Impulsiveness Scale (BIS-11). The median for frequency of trauma exposure was 4 events for people with low and normal impulsivity, and 6 for highly impulsive ones. Individuals with higher impulsivity presented earlier exposition than non-impulsive ones, and worst outcome: $12.4 \%$ with PTSD, against $8.4 \%$ and 2.3\% (normal and low impulsivity). Of the three factors of impulsivity, the Attentional factor conferred the strongest association with PTSD development. Results suggest that impulsivity is also a relevant trait in a non-clinical population and is associated with trauma exposure and PTSD. Strategies to promote mental health in adolescents may be pertinent, especially with the aim of managing impulsivity. (c) 2016 Elsevier Ireland Ltd. All rights reserved.
\end{abstract}

\section{Introduction}

Since the inception of PTSD as a concept, impulsive behavior has been recognized as an associated feature (American Psychiatric Association, 1980). Some researchers have even asserted that PTSD could be characterized in terms of generalized impulsivity (Goodwin and Guze, 1984; Helzer et al., 1987). Nevertheless, the association between impulsivity and PTSD is still underexplored; when present, it has usually been in a clinical sample, and mostly comorbid with other psychiatric disorders (Stanford et al., 2009).

Impulsivity is an essential trait of personality, relevant to explaining normal individual differences-not always with negative consequences (Cloninger, 1987; Costa and McCrae, 1985; Eysenck and Eysenck, 1977; Zuckerman, 1979)—as well as a wide range of

\footnotetext{
* Correspondence to: R Teotônio Vilela, 225, 705, Pq Bela Vista, 40.279-435 Salvador, Bahia, Brazil.

E-mail address: lianetto@uol.com.br (L.R. Netto).
}

psychiatric disorders such as substance abuse, suicide, personality disorders, bipolar disorder, antisocial behavior, attention-deficit/ hyperactivity disorder (American Psychiatric Association, 1994; Barratt et al., 1997; de Wit, 2009; Links et al., 1999; Nigg, 2003; Swann et al., 2008).

Difficulty restraining impulses also increases potentially risky behavior, such as overspending, getting into fights, self-harming behavior, breaking the law, engaging in risky sexual behavior (Jenkins et al., 2015; Krueger et al., 2007). It means that impulsivity increases the risk of exposure to potentially traumatic stimuli, as well as for PTSD development, creating a complex contribution among neurobiological factors, as well as personality traits, and social environment (Braquehais et al., 2010).

In relation to specific psychological traits and neurobiological functions, impulsivity is associated with a tendency to respond to internal or external stimuli without forethought and without regard to the negative consequences (Caci et al., 2003; Moeller et al., 2001); difficulty persisting in tasks or a diminished ability to focus 
(Lejuez et al., 2010); increased sensitivity to reward and punishment and a diminished ability to delay gratification (Ainslie, 1975; Gray, 1987); a tendency to act on the spur of the moment, with poor future planning (Patton et al., 1995; Whiteside and Lynam, 2001); and a diminished ability to regulate emotion (Whiteside and Lynam, 2001).

One of the most influential models in the explanation of impulsive behavior was proposed by Barratt and Stanford (1995), involving biological, psychological and behavioral aspects. Barratt also created the first self-report measure of impulsiveness, which became the gold-standard measure, and the most widely used self-report impulsiveness scale on psychiatric in both research and clinical settings (Barratt, 1959; Reise et al., 2013; Vasconcelos et al., 2012).

The Barratt Impulsiveness Scale (BIS-11) is a 30 item self-report instrument, designed to measure 3 theoretical subtraits of impulsivity: Attentional (lack of focus on the ongoing task), Motor (acting without thinking), and Non-Planning (lack of "futuring" or forethought) (Patton et al., 1995). According to Stanford et al. (2009) in their review of the BIS usage, although many researchers agree with Barratt's conclusion that impulsivity is a multi-faceted construct, the majority of studies using the BIS-11 have reported only the total score, ignoring the second-order subscale. This leads to a less accurate perspective in the characterization of an individual's impulsiveness, and its relationship with different clinical syndromes. Stanford et al. (2009) also suggests that a BIS-11 total score has as normal limit for impulsiveness, with a good concurrent validity.

In spite of Post-traumatic Stress Disorder (PTSD) being a particularly interesting disorder for increasing the understanding of impulsivity, PTSD studies using BIS-11 are rare. Also, the scale has been used mostly within clinical populations, rarely reporting the second-order subscale scores (Malloy-Diniz et al., 2010).

We are unaware of any existing research that studies impulsivity among college students in a population-based design, although these young, and naturally more impulsive group, were shown to be at-risk for exposure to violence and other traumatic situations (Netto et al., 2010; Rigotti et al., 2004; Wechsler and Nelson, 2008), as well as for developing PTSD (Netto et al., 2013). The aim of this study was to explore the impulsivity pattern of Brazilian college students and to investigate the association across levels of impulsivity with trauma exposure and PTSD development in this non-clinical population.

\section{Methods/Design}

\subsection{Study design}

A one-phase census survey of seven college institutions in three metropolitan regions in Northeastern Brazil.

\subsection{Setting}

Brazil has 27 states, of which 9 belong to the Northeastern region and represent 6 of the 10 most violent states in the country (Waiselfisz, 2012). Also, among the 50 cities ranked most violent in the world, 19 are in Brazil; among the 20 most violent cities in the world, 6 are in Northeastern Brazil (Sanchez, 2015). According to census data on college education, the Northeastern region of the country has become the region with the second-highest concentration of undergraduate students (INEP, 2011). This represents a significant segment of Brazilian society that has been poorly investigated.

\subsection{Sampling procedure}

Seven college institutions were selected for reasons of convenience in three urban areas of Bahia and Paraiba states. In order to select representative college institutions, we sought to include three public ( 2 federal and 1 state) and four private colleges in Northeastern Brazil. Since students very often attend university outside their native city, efforts were made to capture a broad profile of Northeastern college students by selecting colleges with student high migration rates (Fonaprace, 2011). Due to budget limitations, we also selected universities according to their accessibility in terms of distance from our work location.

The preparatory procedures for the collection began in October 2010, with a pilot application in 30 undergraduate students. From February to April 2011, 18 college students were trained to work as investigators together with the three main researchers (LRN, JLP, JRFN). The training course comprised a 10-h theoretical module, followed by a field application conducted by the authors and regular subsequent supervision meetings.

On March 2011, classes from all academic departments of the 7 institutions were chosen for each program. From April to July 2011 the data were collected. The inclusion criteria were: all students from their first and final semester in all academic areas, matriculated at the university and attending classes, aged 18 years or older.

From the 2589 eligible students, 2213 were included $(85.5 \%)$; 307 declined to participate (11.8\%), and 69 (2.7\%) did not conclude the questionnaires.

\subsection{Measurements}

The self-applied protocol included a fully structured socio-demographic questionnaire along with three scales, which had been previously translated and adapted to Brazilian Portuguese. All participants answered the full assessment anonymously, which lasted approximately $20-30 \mathrm{~min}$

\subsubsection{Socio-demographics}

Included gender, age, marital status, employment status, parents' educational level, annual family income, migration history, and parents' marital status.

\subsubsection{Exposure to traumatic events}

Assessed through the Trauma History Questionnaire (THQ) (Fiszman et al., 2005), which is a list of 23-items that examines experiences with potentially traumatic events using a yes/no format, and includes 1 item that allows subjects to report on any personal experiences that were not captured in the other items. Information on the frequency and age(s) at the time(s) of exposure was also obtained. At the end, participants are asked to select, from the items identified on the THQ the event they found the most distressing. The Brazilian version of THQ has received a transcultural adaptation (Fiszman et al., 2005) which is widely accepted.

\subsubsection{Mental health}

a) PTSD (assessed through the PTSD Checklist-PCL-Civilian): the instrument is comprised of 17 items based on the diagnostic criteria of the DSM-IV for PTSD. The Brazilian version of PCL-C received a transcultural adaptation (Berger et al., 2004; Bringhenti et al., 2010; Wilkins et al., 2011), considered satisfactory. In this study the diagnosis was made combining two methods to improve accuracy, ensuring that an individual has sufficient severity as well as the necessary pattern of symptoms required by the DSM-IV. The first method requires 
that the individual meet at least one B item, at least three $C$ items and at least two D items, each from DSM-IV. Symptoms rated as "Moderately" or greater are considered clinically meaningful (National Center of PTSD, 2012). The second method determines whether the total severity score exceeds a given cut-off point. Based on Adkins et al. (2008), which used civilian trauma-exposed undergraduates to explore and compare the psychometric properties of seven self-reported measures of PTSD, the adopted cut-off point for PCL-C was $\geq 45$. According to the authors, this optimally efficient cut-off score, previously found for this population, yields a sensitivity of 0.78 and specificity of 0.92 , positive predictive value of 0.54 , negative predictive value of 0.97 . In the instructions on how to fill-in the PCL-C, the subject was instructed to anchor their answers to the worst trauma he/she had experienced according to the Trauma History Questionnaire, and was asked to report how much he/she has been troubled by the listed problems and complaints in the past month. The PCL being anchored to a specific trauma may be more likely to capture PTSD, increasing its discriminant validity from depression, social phobia and anxiety (Wilkins et al., 2011).

b) Impulsivity (assessed through BIS-11 (von Diemen et al., 2007)); this 30-item self-administered scale assesses the presence of impulsive manifestations from the theoretical model proposed by Ernst Barratt, through 3 factors: Motor, Attentional and Lack of Planning (Patton et al., 1995). It is the most widely used scale for clinical and research proposes. The internal consistency coefficient of BIS Total (Patton et al., 1995) differed among populations: for college students the Cronbach's coefficient alpha was 0.82 (mean $63.82 \pm 10.17$ ). The internal consistency coefficient of BIS Sub-factors (Miller et al., 2004) for Motor impulsivity was 0.70 (mean $22.4 \pm 4: 46)$, for Non-Planning was $0.72(24.23 \pm 4: 49)$, and for Attentional was $0.61(16: 53 \pm 3.30)$.

c) A socio-demographic questionnaire to disclose at-risk behaviors, based on Rigotti et al. (2004) and Wechsler and Nelson (2008), included:

Questions about Alcohol, tobacco and other illicit psychoactive substance consumption (aiming to investigate the substance use pattern: first use, current use, frequency, quantity, interpersonal consequences). Sexual risk behaviors ad Suicide (assessed through Yes/No questions).

\subsection{Data analyses}

2.5.1. Description of participants' characteristics by means of univariate analyses: age, gender, parental educational level, origin (being local or from another city), attending semester, and family income.

2.5.2. Total score of BIS-11 was divided through a given cut-off (Stanford et al., 2009), and was associated with clinical and demographic characteristics through crosstabulation. Each of the three-component factors of BIS-11 (second-order subscale) were divided into tertiles and associated with clinical and demographic characteristics through crosstabulation as well.

2.5.3. Impulsivity was explored as an independent variable through hierarchical multivariate analysis, and adjusted for age and gender, to obtain Odds Ratio (Santos et al., 2011). Two models were created in order to investigate the causal pathway for the effect of impulsivity on PTSD outcome, decomposing its total effect (not mediated) and its direct effect as a risk factor for PTSD. In both models, annual familial income and parents' education level were variables included as distals. This construct is based on Ludermir $1^{\text {st }}$ Level:

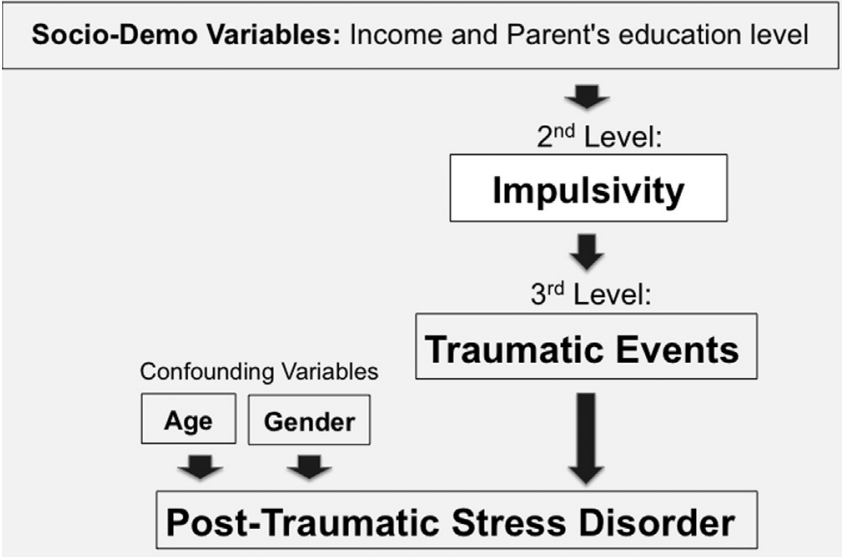

Fig. 1. Hierarchical conceptual Model A: impulsivity as intermediate variable.

and Lewis (2001) which observed that disadvantages in social condition, such as education and income are the most powerful indicators related to common mental disorders. From the perspective of Gerard and Higley (2002), this suggests an adaptive role of impulsivity in the context of high levels of environmental adversity. In MODEL A: Impulsivity was analyzed as intermediate variable from the outcome (Fig. 1) according to a neurobiological perspective that comprehends impulsivity as a trait usually formed in an early phase of human development. Previous studies have shown that an increased manifestation of this trait can mediate risk behaviors and higher exposure to potentially traumatic events (Araújo et al., 2009; Malloy-Diniz et al., 2010).

In MODEL B: Impulsivity was analyzed as proximal variable from PTSD (Fig. 2), as defined on the basis of a biopsychosocial approach, considering that impulsive behavior is a result of several different and independent factors, which interact to better adapt to the environmental cues (Dickman, 1990; Evenden, 1999). Age and gender were controlled as confounding variables in both models.

\section{Results}

The analyses were conducted within a population of 2213 subjects, of whom 308 (14\%) had low impulsivity based on BIS total score, 1537 (70.1\%) had normal range of impulsivity, and 348 (15.9\%) presented high impulsivity. Women had higher impulsivity

$1^{\text {st }}$ Level:

Socio-Demo Variables: Income and Parent's education leve

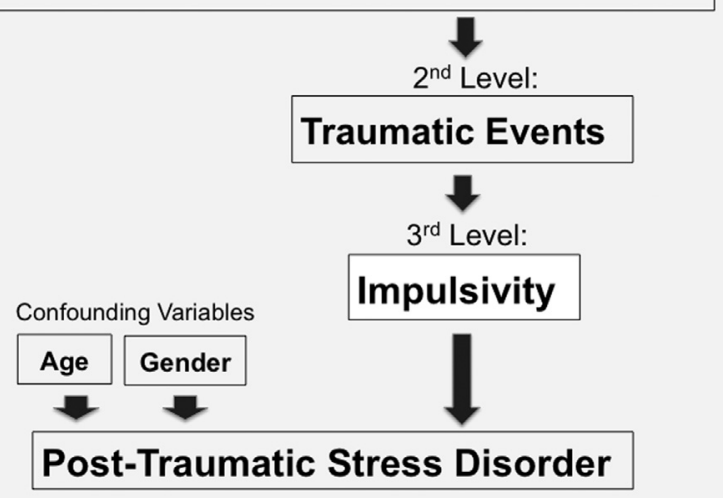

Fig. 2. Hierarchical conceptual Model B: impulsivity as proximal variable. 
Table 1

Socio-demographic characteristics of college students in Northeastern Brazil and impulsivity patterns.

\begin{tabular}{|c|c|c|c|c|c|}
\hline Socio-demo variables & & $\begin{array}{l}\text { Total } \\
\text { N (\%) }\end{array}$ & $\begin{array}{l}\text { Low impulsivity } \\
308(14 \%)\end{array}$ & $\begin{array}{l}\text { Normal impulsivity } \\
1537 \text { (70.1\%) }\end{array}$ & $\begin{array}{l}\text { High impulsivity } \\
348(15.9 \%)\end{array}$ \\
\hline Gender & $\begin{array}{l}\text { Female } \\
\text { Male }\end{array}$ & $\begin{array}{r}1463(66.1) \\
750(33.9)\end{array}$ & $\begin{array}{l}187(12.8) \\
125(16.6)\end{array}$ & $\begin{array}{r}1020(69.7) \\
522(69.6)\end{array}$ & $\begin{array}{l}256(17.5) \\
103(13.8)\end{array}$ \\
\hline Age & $\begin{array}{l}\leq 22 \text { Years } \\
>22 \text { Years }\end{array}$ & $\begin{array}{l}1138(51.4) \\
1075(48.6)\end{array}$ & $\begin{array}{l}164(14.4) \\
147(13.7)\end{array}$ & $\begin{array}{l}779(68.5) \\
768(71.4)\end{array}$ & $\begin{array}{l}195(17.2) \\
160(14.9)\end{array}$ \\
\hline Marital status $^{a}$ & $\begin{array}{l}\text { Single } \\
\text { Married } \\
\text { Divorced }\end{array}$ & $\begin{array}{c}1789(80.8) \\
352(15.5) \\
28(1.2)\end{array}$ & $\begin{array}{c}252(13.7) \\
56(15.9) \\
2(7.1)\end{array}$ & $\begin{array}{r}1283(69.5) \\
252(71.6) \\
22(78.6)\end{array}$ & $\begin{array}{r}311(16.8) \\
44(12.5) \\
4(14.3)\end{array}$ \\
\hline Origin $^{\mathrm{a}}$ & $\begin{array}{l}\text { Local } \\
\text { Non-local }\end{array}$ & $\begin{array}{r}879(43.2) \\
1158(56.8)\end{array}$ & $\begin{array}{l}145(16.5) \\
142(12.3)\end{array}$ & $\begin{array}{l}610(69.4) \\
814(70.3)\end{array}$ & $\begin{array}{l}124(14.1) \\
202(17.4)\end{array}$ \\
\hline Annual fam. income ${ }^{a}$ & $\begin{array}{l}\leq \text { US 5,472 } \\
\geq \text { US 26,448 }\end{array}$ & $\begin{array}{r}1282(59.4) \\
676(40.6)\end{array}$ & $\begin{array}{r}141(14.2) \\
96(14.3)\end{array}$ & $\begin{array}{l}699(70.5) \\
467(69.4)\end{array}$ & $\begin{array}{l}152(15.3) \\
110(16.3)\end{array}$ \\
\hline Semester & $\begin{array}{l}\text { First } \\
\text { Final }\end{array}$ & $\begin{array}{r}1260(56.9) \\
953(43.1)\end{array}$ & $\begin{array}{l}169(13.4) \\
142(14.9)\end{array}$ & $\begin{array}{l}876(69.5) \\
671(70.4)\end{array}$ & $\begin{array}{l}215(17.1) \\
140(14.8)\end{array}$ \\
\hline Father's educ. level ${ }^{a}$ & $\begin{array}{l}\text { None } \\
\text { Elementary } \\
\text { Middle school } \\
\text { College } \\
\text { Postgraduate }\end{array}$ & $\begin{array}{c}91(4.2) \\
1047(48.4) \\
690(31.9) \\
236(10.9) \\
100(4.6)\end{array}$ & $\begin{array}{r}10(10.6) \\
149(14.2) \\
93(13.5) \\
32(13.5) \\
18(17.6)\end{array}$ & $\begin{array}{c}65(71.3) \\
743(71) \\
486(70.4) \\
158(66.8) \\
64(63.7)\end{array}$ & $\begin{array}{r}16(18.1) \\
155(14.8) \\
111(16.2) \\
46(19.7) \\
19(18.6)\end{array}$ \\
\hline Mother's educ. level $^{\mathrm{a}}$ & $\begin{array}{l}\text { None } \\
\text { Elementary } \\
\text { Middle school } \\
\text { College } \\
\text { Postgraduate }\end{array}$ & $\begin{array}{l}71(3.3) \\
825(38.1) \\
786(36.3) \\
299(13.8) \\
206(8.5)\end{array}$ & $\begin{array}{c}7(9.6) \\
126(15.3) \\
101(12.8) \\
48(15.9) \\
25(12.1)\end{array}$ & $\begin{array}{r}52(72.6) \\
591(71.6) \\
557(70.9) \\
189(63.3) \\
140(67.9)\end{array}$ & $\begin{array}{r}12(17.8) \\
108(13.1) \\
128(16.3) \\
62(20.8) \\
41(20)\end{array}$ \\
\hline Academic area & $\begin{array}{l}\text { Exact sciences } \\
\text { Biological sciences } \\
\text { Human sciences }\end{array}$ & $\begin{array}{r}285(12.9) \\
502(22.7) \\
1426(64.4)\end{array}$ & $\begin{array}{r}44(15.3) \\
73(14.5) \\
194(13.6)\end{array}$ & $\begin{array}{l}205(71.9) \\
357(71.2) \\
984(69)\end{array}$ & $\begin{array}{r}36(12.9) \\
72(14.3) \\
248(17.4)\end{array}$ \\
\hline
\end{tabular}

${ }^{a}$ Frequency and percentage over the valid answers.

scores than men, with BIS total mean score of 62.1 and 60.6 respectively. The mean score for the second-order subscales had small differences between genders.

Students from first semester presented higher impulsivity scores (mean of 62 and 61 respectively), as well as non-local students (mean of 62.2 and 60.7 respectively), and younger students (mean of 61.9 for students with age $\leq 22$ years and 61.1 for those who were older than 22 years). The mean score for the second-order subscales (Motor, Attentional and Non-Planning) presented minor differences among the variables semester, origin and age.

Students from the Exact Sciences presented the highest prevalence of low impulsivity (15.3\%), and students from Human Science/Arts presented the highest prevalence of high impulsivity (17.4\%) (Table 1).

The total PTSD prevalence in the study was $14 \%$, among which the most impulsive were the most affected (51.4\% of PTSD subjects, with OR: 2.90 ; $95 \% \mathrm{CI} 2.16-3.90$ for the high impulsive group). Of the three factors of impulsivity, the Attentional factor conferred the strongest association with PTSD development (OR: 2.27; 95\% CI 1.60-3.21), and $48 \%$ of the students who were classified as more attentionally impulsive presented PTSD. On the other hand, higher levels of the Lack of Planning factor did not show a considerable association with PTSD: the ORs of the less impulsive group (1.21; 95\% CI $0.84-1.75)$ and the more impulsive one (1.36; 95\%CI $1.01-$ 1.82 ) are included in each other CI. Lower Motor impulsivity levels were frequent $(43 \%$ of the students were concentrated in the first tertile) and were associated with lower prevalence of PTSD. A lower Non-Planning impulsivity level was also frequent (with $39.7 \%$ of the students concentrated in the first tertile), but both lower and higher levels of this factor were associated with an increased prevalence of PTSD (Table 2).

The median for frequency of trauma exposure was 4 events for low and normal impulsive people, and 6 for high impulsive ones. Individuals with higher impulsivity presented earlier exposition and worse outcomes (12.4\% with PTSD, against $8.4 \%$ and $2.3 \%$ for normal and low impulsive ones). In terms of categories of trauma, high impulsivity was associated with greater exposure to all of 
Table 2

Impulsivity and its factors in association and odds ratio for Post-Traumatic Stress Disorder in Northeastern Brazilian college students.

\begin{tabular}{|c|c|c|c|c|c|}
\hline $\begin{array}{l}\text { Impulsivity } \\
\text { factors }\end{array}$ & $\begin{array}{l}\text { Impulsivity } \\
\text { levels }\end{array}$ & $\begin{array}{l}\text { Odds } \\
\text { ratio }\end{array}$ & $95 \% \mathrm{CI}$ & $\begin{array}{l}\text { Students } \\
\text { with PTSD } \\
\mathrm{N}(\%)\end{array}$ & $\begin{array}{l}\text { Total of stu- } \\
\text { dents N (\%) }\end{array}$ \\
\hline BIS Total & $\begin{array}{l}\text { Low } \\
\text { impulsivity }\end{array}$ & 0.68 & $0.43-1.09$ & $7(2.3)$ & 308 (14) \\
\hline \multirow[t]{2}{*}{$(\mu=61.5)$} & $\begin{array}{l}\text { Normal } \\
\text { impulsivity }\end{array}$ & & & $129(8.4)$ & $1537(70.1)$ \\
\hline & $\begin{array}{l}\text { High } \\
\text { impulsivity }\end{array}$ & 2.90 & $2.16-3.90$ & $43(12.8)$ & 348 (15.9) \\
\hline $\begin{array}{l}\text { Motor } \\
\text { impulsivity }\end{array}$ & $\begin{array}{l}\text { Less } \\
\text { impulsivity }\end{array}$ & 0.91 & $0.63-1.31$ & 50 (27.9) & $944(43)$ \\
\hline \multirow[t]{2}{*}{$(\mu=19.6)$} & $\begin{array}{l}\text { Average } \\
\text { impulsivity }\end{array}$ & & & $59(33)$ & $620(28.3)$ \\
\hline & $\begin{array}{l}\text { More } \\
\text { impulsivity }\end{array}$ & 1.76 & $1.25-2.47$ & $70(39.1)$ & 629 (28.7) \\
\hline \multirow[t]{3}{*}{$\begin{array}{l}\text { Attentional } \\
\text { impulsivity }\end{array}$} & $\begin{array}{l}\text { Less } \\
\text { impulsivity }\end{array}$ & 0.62 & $0.42-0.92$ & $26(14.5)$ & $728(33.2)$ \\
\hline & $\begin{array}{l}\text { Average } \\
\text { impulsivity }\end{array}$ & & & $67(37.4)$ & $750(34.2)$ \\
\hline & $\begin{array}{l}\text { More } \\
\text { impulsivity }\end{array}$ & 2.27 & $1.60-3.21$ & $86(48)$ & 715 (32.6) \\
\hline $\begin{array}{l}\text { Lack of Plan- } \\
\text { ning } \\
\text { Impulsivity }\end{array}$ & $\begin{array}{l}\text { Less } \\
\text { impulsivity }\end{array}$ & 1.21 & $0.84-1.75$ & $63(35.2)$ & 871 (39.7) \\
\hline \multirow[t]{2}{*}{$(\mu=24.7)$} & $\begin{array}{l}\text { Average } \\
\text { impulsivity }\end{array}$ & & & 39 (21.8) & $597(27.2)$ \\
\hline & $\begin{array}{l}\text { More } \\
\text { impulsivity }\end{array}$ & 1.36 & $1.01-1.82$ & 77 (43) & 725 (33.1) \\
\hline
\end{tabular}

PTSD: Post-Traumatic Stress Disorder; CI: Confidence Interval; BIS: Barratt Impulsivity Scale. Normal impulsivity was used as reference to calculate odds ratio.

them, except Natural Disaster. Lower impulsivity individuals presented higher frequency on the categories of Non-sexual Violence, Witness to Death or Serious Injury, and Accidents.

When impulsivity was explored through hierarchical multivariate analysis and considered as intermediate variable (Model A), the chance of PTSD increased for all categories of trauma but Sexual Violence and Witness to Death. In these two categories, high levels of impulsivity modestly diminished the PTSD odds. An impulsivity effect may be observed due to a reduction in the OR when the proximal variable (type of trauma) was introduced (direct effect).

When impulsivity was explored as proximal variable (Model B), it acted as a protection factor in relation to Man-Made Disasters, Violence-associated Trauma, Witness to Death or Serious Injury, Accidents, and Other Traumas. An impulsivity effect may be observed in Model B due to an increase in the OR when it was introduced (direct effect). The chance of PTSD increased when faced with Natural Disasters, and made no difference for Life-Threatening Illness (Table 3).

Students with high impulsivity had about six times more PTSD than students with low impulsivity (12.4-2.3\%). Among higher impulsivity subjects, there was also observed increased attempted suicide (14.8-2.9\%), sexual risk behavior (26.7-7.1\%) and daily use of alcohol (1.6-0\%) in comparison with those of normal or low impulsivity (Table 4).

\section{Discussion}

To our knowledge, this is the first population-based study to investigate the association between patterns of impulsivity and PTSD. We found that increased impulsive behaviors were highly associated with a greater prevalence of PTSD, attempted suicide, sexual risk behavior and daily use of alcohol, which is in agreement with previous clinical studies (Shin et al., 2012; Swann et al. 2002). Therefore, for all at-risk behavior, low impulsivity acted as a protection factor

When explored through hierarchical multivariate analysis and considered as intermediate variable, impulsivity showed an increased association with almost all categories of trauma, with greater OR for PTSD, which is well established in the literature (Braquehais et al., 2010). This suggests that impulsivity increases the odds of exposure to potentially traumatic stimuli, as well as the chance of PTSD development in this young population. The two exceptions were Sexual Violence and Witness to Death, categories for which impulsiveness appeared as protective. It could mean that an important part in the development of PTSD is due to the nature of the event itself. Another hypothesis is that impulsive individuals may make more accurate decisions than reflective ones in situations requiring rapid action (Caci et al., 2003).

When explored as a proximal variable, impulsivity reduced the OR for PTSD prevalence for all traumas except Life-Threatening Illness and Natural Disaster. This is an interesting outcome, wherein impulsivity can be comprehended as a protection factor, with not only negative consequences.

One possible reflection upon this result is that while peritraumatic dissociation is considered a risk factor for PTSD development (Fullerton et al., 2000), the 'drive disinhibition' associated with a prefrontal-hypothalamic-amygdaloid complex (Brutkowski, 1965 ) in the face of traumatic cues could constitute a protective response. This would be due to greater motor activation, considered one of the three basic components of impulsivity (Patton et al., 1995), which is probably not adaptive for dealing with LifeThreatening Illness needs for recovery. Another hypothesis for the protective effect of the impulsivity is that it can provoke some kind of habituation in the face of frequent exposure - which did not happen with the category of Natural Disaster in our population (only $6.2 \%$ of the students experienced this kind of event, while $29.2 \%$ of them presented PTSD).

Our attention was drawn to the high prevalence of low impulsivity individuals that had experienced violence-related events, reinforcing that this is an at-risk population for exposure to violence.

When the mean total score of the BIS- 11 scale in our population is compared with results from other non-clinical samples (Fossati et al., 2002; Leshem and Glicksohn, 2007; Patton et al., 1995; Soeiro-De-Souza et al., 2013), we observed a relatively low mean for BIS total score in our subjects. None of the previous studies using BIS-11 in PTSD subjects adopted a cut-off (Ariga et al., 2010; Depue et al., 2014; Oquendo et al., 2005; Moeller et al., 2001; Nelson et al., 2013; Swick et al., 2013), which results in the absence of previous parameters for comparison. Our result (15.9\% of the population presented high impulsivity, and $14 \%$ presented low impulsivity) seems to be coherent with the clinical background.

The Attentional factor in this study, in comparison with the other sub-scale factors, presented greater odd of developing PTSD (OR 2.27; 95\% CI 1.60-3.21). Bardeen and Orcutt (2011) have suggested that Attentional processes are a factor leading to maintenance and exacerbation of posttraumatic stress symptoms, such as intrusive thoughts, flashbacks, physiological reactivity, avoidance behaviors and heightened arousal. Also it has been suggested that the Attentional factor could be a general process underlying the personality trait of impulsiveness as a whole (Sonuga-Barke, 
Table 3

Prevalence of trauma exposition according to impulsivity pattern and Odds Ratio for Post-Traumatic Stress Disorder in Northeastern Brazilian College Students.

\begin{tabular}{|c|c|c|c|c|c|c|c|c|}
\hline BIS & $\begin{array}{l}\text { Life-threatening } \\
\text { illness } \\
\mathrm{N}(\%)\end{array}$ & $\begin{array}{l}\text { Witness to death/ } \\
\text { injury } \\
\mathrm{N}(\%)\end{array}$ & $\begin{array}{l}\text { Non-sexual } \\
\text { violence } \\
\mathrm{N}(\%)\end{array}$ & $\begin{array}{l}\text { Sexual } \\
\text { violence } \\
\mathrm{N}(\%)\end{array}$ & $\begin{array}{l}\text { Natural } \\
\text { disaster } \\
\mathrm{N}(\%)\end{array}$ & $\begin{array}{l}\text { Accidents } \\
\mathrm{N}(\%)\end{array}$ & $\begin{array}{l}\text { Man-made } \\
\text { disaster } \\
\mathrm{N}(\%)\end{array}$ & $\begin{array}{l}\text { Other } \\
\text { trauma } \\
\mathrm{N}(\%)\end{array}$ \\
\hline Low impulsivity & $30(9.7)$ & $247(77.2)$ & $208(65)$ & $20(6.3)$ & $22(6.9)$ & $85(26.6)$ & $21(6.6)$ & $28(8.8)$ \\
\hline Normal impuls. & $156(10.2)$ & $1303(81.7)$ & $1002(62.8)$ & $144(9)$ & $104(6.5)$ & $473(29.7)$ & $99(6.2)$ & $139(8.7)$ \\
\hline High impulsivity & $42(12)$ & $315(85.8)$ & 256 (69.8) & $48(13.1)$ & $24(6.5)$ & $119(32.4)$ & $32(8.7)$ & 40 (10.9) \\
\hline Total & $228(10.4)$ & 1865 (81.7) & $1466(64.2)$ & $212(9.3)$ & $150(6.5)$ & 677 (29.7) & $152(6.7)$ & $207(9.1)$ \\
\hline $\begin{array}{l}\text { Model A: OR (dir. effect) } \\
\quad(95 \% \mathrm{CI})\end{array}$ & $\begin{array}{l}2.41 \\
(1.69-3.45)\end{array}$ & $\begin{array}{l}3.52 \\
(2.14-5.81)\end{array}$ & $\begin{array}{l}2.12 \\
(1.56-2.87)\end{array}$ & $\begin{array}{l}3.47 \\
(2.44-4.92)\end{array}$ & $\begin{array}{l}2.74 \\
(1.79-4.20)\end{array}$ & $\begin{array}{l}1.79 \\
(1.36-2.36)\end{array}$ & $\begin{array}{l}1.40 \\
(0.95-2.07)\end{array}$ & $\begin{array}{l}1.48 \\
(1.01-2.17)\end{array}$ \\
\hline $\begin{array}{l}\text { Model B: OR (total effect) } \\
\quad(95 \% \mathrm{CI})\end{array}$ & $\begin{array}{l}2.40 \\
(1.69-3.40)\end{array}$ & $\begin{array}{l}3.67 \\
(2.23-6.01)\end{array}$ & $\begin{array}{l}2.20 \\
(1.63-2.97)\end{array}$ & $\begin{array}{l}3.67 \\
(2.60-5.17)\end{array}$ & $\begin{array}{l}2.59 \\
(1.70-3.93)\end{array}$ & $\begin{array}{l}1.83 \\
(1.39-2.39)\end{array}$ & $\begin{array}{l}1.54 \\
(1.05-2.26)\end{array}$ & $\begin{array}{l}1.55 \\
(1.06-2.26)\end{array}$ \\
\hline $\begin{array}{l}\text { Model B: OR (dir. effect) } \\
\quad(95 \% \mathrm{CI})\end{array}$ & $\begin{array}{l}2.41 \\
(1.69-3.46)\end{array}$ & $\begin{array}{l}3.52 \\
(2.14-5.81)\end{array}$ & $\begin{array}{l}2.09 \\
(1.54-2.82)\end{array}$ & $\begin{array}{l}3.47 \\
(2.44-4.92)\end{array}$ & $\begin{array}{l}2.74 \\
(1.79-4.21)\end{array}$ & $\begin{array}{l}1.72 \\
(1.31-2.25)\end{array}$ & $\begin{array}{l}1.41 \\
(0.95-2.07)\end{array}$ & $\begin{array}{l}1.43 \\
(0.98-2.08)\end{array}$ \\
\hline
\end{tabular}

Model A: OR obtained through hierarchical conceptual analysis, having impulsivity as an intermediate variable. Odds ratio for comparison with the total effect: 2.90 . Model B: OR obtained through hierarchical conceptual analysis, having impulsivity as a proximal variable.

In both models: Annual Familial Income and Parents' Education Level were included as distal variables; Age and Gender were variables controlled as confounders. CI: confidence interval; OR: odds ratio.

Table 4

Prevalence of impulsivity, Post-Traumatic Stress Disorder and dysfunctional behaviors, based on BIS cut-off in Northeastern Brazilian College Students.

\begin{tabular}{lccccc}
\hline & N (\%) & PTSD & $\begin{array}{l}\text { Attempted } \\
\text { suicide }\end{array}$ & $\begin{array}{l}\text { Sexual risk } \\
\text { behavior }\end{array}$ & $\begin{array}{l}\text { Daily } \\
\text { use of } \\
\text { alcohol }\end{array}$ \\
\hline $\begin{array}{c}\text { Low } \\
\text { impulsivity }\end{array}$ & $308(14)$ & $7(2.3)$ & $9(2.9)$ & $22(7.1)$ & $0(0)$ \\
$\begin{array}{c}\text { Normal } \\
\text { impulsivity } \\
\text { High } \\
\text { impulsivity }\end{array}$ & $1537(70.1)$ & $129(8.4)$ & $105(6.6)$ & $257(16.4)$ & $4(0.3)$ \\
\begin{tabular}{c} 
Total \\
\hline
\end{tabular} & $2213(100)$ & $310(14)$ & $168(7.4)$ & $376(16.8)$ & $9(0.4)$ \\
\hline
\end{tabular}

BIS: Barratt Impulsivity Scale; PTSD: Post-Traumatic Stress Disorder.

\section{2; Vasconcelos et al., 2012).}

Previous studies have demonstrated an association among high levels of Lack of Planning impulsivity factor and cognitive distortions (de Wit et al., 2007; Mobini et al., 2007). Despite this, Lack of Planning presented the lowest and a negligible association with PTSD compared with the other factors, possibly due to a tertile based analysis. A lack of cut-point resulted in $39.7 \%$ of the students concentrated in the first tertile with both lower and higher levels of Lack of Planning being associated with an increased prevalence of PTSD.

Several limitations need to be considered in interpreting these data. The PCL-C version used for the data collection was based on DSM-IV criteria. The cross-sectional design of the study prevents conclusions about the directionality of the impulsivity-trauma exposure-PTSD relationship. Furthermore, the small differences found in the OR between the direct effect and the total effect of impulsivity, together with a lack of prior references in the literature, prohibit us from reaching a final conclusion about the clinical interpretation of the data.

The non-inclusion of absentee and non-consenting students in the analyses may have resulted in the loss of the most impulsive and/or most severely affected individuals. In addition, memory bias can also occur, resulting in less reliable reports, given that some events may have occurred in the early life of respondents.

As a conclusion, these results suggest that impulsivity is also a relevant trait in a non-clinical population. Through hierarchical multivariate analysis, it was speculated that impulsivity was associated both with some kind of trauma exposure and PTSD development, making direct and indirect contributions to the psychopathological findings.

Strategies to prevent mental disorders and their negative consequences over a lifetime, and to promote mental health in college students, are an important suggestion. Actions could specially aim to introduce to the primary care level: facilities to routinely screen for impulsiveness; educational skills to teach stress and impulsiveness management techniques in crisis situations and to help improving the Attentional system and; pharmacological information to reduce impulsivity and violent or risky behaviors.

Impulsivity gave modest protection in the face of some types of trauma, in both models of hierarchical multivariate analysis. The difference in the OR between the direct effect and the total effect of impulsivity, both as distal and proximal variable, was mostly less than $5 \%$. The prior literature does not provide parameters about which difference would be clinically relevant, but the small differences found in this article can at least identify some tendencies to be investigated in different populations.

Further research would be important to better understand impulsivity as a multifaceted construct, and its effects, integrating data from clinical and non-clinical population.

\section{Acknowledgments}

To The Trauma and Anxiety Disorders Study Group - UFBA: Adriana Duarte, Amanda Loureiro, Deivson Mundim, Isabela Albuquerque, Rana Barbosa, Lilian Carvalho, Susan Carvalho, Reinilza Nunes, Weslley Batista, Maria Rosa-Dantas, Antonio Dantas, Albaniza Formiga, Fernanda Dias, Fransuélio Nascimento, Jesana Damasceno, Perla Soares. To Darci Santos, Mônica Nascimento, Lene Lima, Sidnei Lira, Gisela Guedes, Rubens Lima, Neander Abreu, for their technical assistance.

The funding for the study came from the Edital Universal MCT/ CNPq 14/2010, 474869/2010-5. The funders had no role in study design, data collection and analysis, decision to publish, or preparation of the manuscript. No additional external funding received for this study.

This study was part of a research project aiming to explore key aspects of traumatic experiences in college students in Northeastern Brazil. It has been approved by the Institutional Review Boards of Bahia (CEP/COM/UFBA - process number 227/2010) and Paraíba (CEP/Fac. Sta. Maria, 17-02-2011), Brazil.

\section{References}

Adkins, J.W., Weathers, F.W., McDevitt-Murphy, M., Daniels, J.B., 2008. Psychometric properties of seven self-report measures of posttraumatic stress 
disorder in college students with mixed civilian trauma exposure. J. Anxiety Disord. 22, 1393-1402.

Ainslie, G., 1975. Specious reward: a behavioral theory of impulsiveness and impulse control. Psychol. Bull. 82, 463-496.

American Psychiatric Association, 1980. Diagnostic and Statistical Manual of Mental Disorders, 3rd ed. Author, Washington DC.

American Psychiatric Association, 1994. Diagnostic and Statistical Manual of Mental Disorders, 4th ed. Author, Washington DC.

Araújo, M.M., Malloy-Diniz, L.F., Rocha, F.L., 2009. Impulsividade e acidentes de trânsito. Rev. Psiquiatr. Clín. 36 (2), 60-68.

Ariga, M., Uehara, T., Takeuchi, K., Ishige, Y., Nakano, R., Mikuni, M., 2010. Follow-up study of female delinquent adolescents in a detention centre: effectiveness of psychiatric intervention as a mental health service. Int. J. Soc. Psychiatry 56, $15-22$.

Bardeen, J.R., Orcutt, H.K., 2011. Attentional control as a moderator of the relationship between posttraumatic stress symptoms and attentional threat bias. J. Anxiety Disord. 25, 1008-1018.

Barratt, E.S., 1959. Anxiety and impulsiveness related to psychomotor efficiency. Percept. Mot. Skills 9, 191-198.

Barratt, E.S., Stanford, M.S., 1995. Impulsiveness. In: Costello, C.G. (Ed.), Personality Characteristics of the Personality Disordered. Wiley, New York, NY, pp. 91-119.

Barratt, E.S., Stanford, M.S., Kent, T.A., Felthous, A., 1997. Neuropsychological and cognitive psychophysiological substrates of impulsive aggression. Biol. Psychiatry $41,1045-1061$

Berger, W., Mendlowicz, M.V., Souza, W.F., Figueira, I., 2004. Semantic equivalence of the Portuguese version of the Post-Traumatic Stress Disorder Checklist Civilian Version (PCL-C) for the screening of post-traumatic stress disorder. Rev. Psiquiatr. do Rio Grande do Sul 26, 167-175.

Braquehais, M.D., Oquendo, M.A., Baca-García, E., Sher, L., 2010. Is impulsivity a link between childhood abuse and suicide? Compr. Psychiatry 51, 121-129.

Bringhenti, M.E., Luft, C.D., Oliveira, W.F., 2010. Transtorno do Estresse pos-traumático em acidentes de trânsito: validação de escala. Psico-USF 15, 193-203.

Brutkowski, S., 1965. Functions of prefrontal cortex in animals. Physiol. Rev. 45, $721-746$.

Caci, H., Nadalet, L., Bayle, F.J., Robert, P., Boyer, P., 2003. Functional and dysfunctional impulsivity: contribution to the construct validity. Acta Psychiatr. Scand. 107, 34-40.

Cloninger, C.R., 1987. A systematic method for clinical description and classification of personality variants. A proposal. Arch. Gen. Psychiatry 44, 573-588.

Costa, P.T., McCrae, R.R., 1985. The NEO Personality Inventory Manual. Psychological Assessment Resources, Odessa, FL.

de Wit, H., 2009. Impulsivity as a determinant and consequence of drug use: a review of underlying processes. Addict. Biol. 14, 22-31.

de Wit, H., Flory, J.D., Acheson, A., McCloskey, M., Manuck, S.B., 2007. IQ and nonplanning impulsivity are independently associated with delay discounting in middle-aged adults. Personal. Individ. Differ. 42, 111-121.

Depue, B.E., Olson-Madden, J.H., Smolker, H.R., Rajamani, M., Brenner, L.A., Banich, M.T., 2014. Reduced amygdala volume is associated with deficits in inhibitory control: a voxel- and surface-based morphometric analysis of comorbid PTSD/ mild TBI. BioMed Res. Int. 2014, 691505.

Dickman, S.J., 1990. Functional and dysfunctional impulsivity: personality and cognitive correlates. J. Personal. Soc. Psychol. 58, 95-102.

Evenden, J.L., 1999. Varieties of impulsivity. Psychopharmacology 146, 348-361.

Eysenck, S.B., Eysenck, H.J., 1977. The place of impulsiveness in a dimensional system of personality description. Br. J. Soc. Clin. Psychol. 16, 57-68.

Fiszman, A., Cabizuca, M., Lanfredi, C., Figueira, I., 2005. The cross-cultural adaptation to Portuguese of the Trauma History Questionnaire to identify traumatic experiences. Rev. Bras. Psiquiatr. 27, 63-66.

Fonaprace, 2011. Perfil Socioeconômico e Cultural dos Estudantes de Graduação das Universidades Federais Brasileiras. In: FONAPRACE (Ed.), Fórum Nacional de Pró-Reitores de Assuntos Comunitários e Estudantis. FONAPRACE, Brasília.

Fossati, A., Barratt, E.S., Acquarini, E., Di Ceglie, A., 2002. Psychometric properties of an adolescent version of the Barratt Impulsiveness Scale-11 for a sample of Italian high school students. Percept. Mot. Skills 95, 621-635.

Fullerton, C.S., Ursano, R.J., Epstein, R.S., Crowley, B., Vance, K.L., Kao, T.C., Baum, A., 2000. Peritraumatic dissociation following motor vehicle accidents: relationship to prior trauma and prior major depression. J. Nerv. Mental Dis. 188, 267-272.

Gerard, M.S., Higley, J.D., 2002. Evolutionary underpinnings of excessive alcohol consumption. Addiction 97, 415-425.

Goodwin, D.W., Guze, S.B., 1984. Psychiatric Diagnosis. Oxford University Press, Oxford, England.

Gray, J.A., 1987. Perspectives on anxiety and impulsivity. J. Res. Personal. - Comment. 21, 493-509.

Helzer, J.E., Robins, L.N., McEvoy, L., 1987. Post-traumatic stress disorder in the general population. Findings of the epidemiologic catchment area survey. N. Engl. J. Med. 317, 1630-1634.

INEP, 2011. Censo da Educação Superior no Brasil 2010. In: Educação, M.D. (Ed.). Instituto Nacional de Estudos e Pesquisas Educacionais Anísio Teixeira, Brasília, Brazil, p. 24.

Jenkins, A.L., McCloskey, M.S., Kulper, D., Berman, M.E., Coccaro, E.F., 2015. Selfharm behavior among individuals with intermittent explosive disorder and personality disorders. J. Psychiatr. Res. 60, 125-131.

Krueger, R.F., Markon, K.E., Patrick, C.J., Benning, S.D., Kramer, M.D., 2007. Linking antisocial behavior, substance use, and personality: an integrative quantitative model of the adult externalizing spectrum. J. Abnorm. Psychol. 116, 645-666.
Lejuez, C.W., Magisdson, S.H., Mitchell, R.S., Stevens, M.C., de Wit, H., 2010. Behavioral and biological indicators of impulsivity in the development of alcohol use, problems, and disorders. Alcohol.: Clin. Exp. Res. 34, 1334-1345.

Leshem, R., Glicksohn, J., 2007. The construct of impulsivity revisited. Personal. Individ. Differ. 43, 681-691.

Links, P.S., Heslegrave, R., van Reekum, R., 1999. Impulsivity: core aspect of borderline personality disorder. J. Personal. Disord. 13, 1-9.

Ludermir, A.B., Lewis, G., 2001. Links between social class and common mental disorders in Northeast Brazil. Soc. Psychiatry Psychiatr. Epidemiol. 36 (3), 101-107.

Malloy-Diniz, L.F., Mattos, P., Leite, W.B., Abreu, N., Coutinho, G., Paula, J.J., Tavares, H., Vasconcelos, A.G., Fuentes, D., 2010. Translation and cultural adaptation of Barratt Impulsiveness Scale (BIS-11) for administration in Brazilian adults. J. Bras. Psiquiatr. 59 (2), 99-105.

Miller, E., Joseph, S., Tudway, J., 2004. Assessing the component structure of four self-report measures of impulsivity. Personal. Individ. Differ. 37, 349-358.

Mobini, S., Grant, A., Kass, A., Yeomans, M., 2007. Relationships between functional and dysfunctional impulsivity, delay discounting and cognitive distortions. Personal. Individ. Differ. 43, 1517-1528.

Moeller, F.G., Barratt, E.S., Dougherty, D.M., Schmitz, J.M., Swann, A.C., 2001. Psychiatric aspects of impulsivity. Am. J. Psychiatry 158, 1783-1793.

National Center of PTSD, 2012. Using PTSD Checklist (PCL). US Departament of Veterans Affairs, United States 〈http://www.ptsd.va.gov

Netto, L.R., K. K., Mari, J.d.J., Ribeiro, W.S., Mello, M.F., et al., 2010. The Impact of violence on the mental health of people living in urban centers in Brazil. In: The Psychological Impact of Living Under Violence and Poverty in Brazil. Nova Science Publishers, New York, NY, pp. 79-90.

Netto, L.R., Cavalcanti-Ribeiro, P., Pereira, J.L., Nogueira, J.F., Santos, L.L., Lira, S.B., Guedes, G.M., Teles, C.A., Trauma, A.D.S.G.U., Koenen, K.C., Quarantini, L.C., 2013. Clinical and socio-demographic characteristics of college students exposed to traumatic experiences: a census of seven college institutions in Northeastern Brazil. PLoS ONe 8, e78677.

Nelson, E.C., Heath, A.C., Lynskey, M.T., Agrawal, A., Henders, A.K., Bowdler, L.M., Todorov, A.A., Madden, P.A., Moore, E., Degenhardt, L., Martin, N.G., Montgomery, G.W., 2013. PTSD risk associated with a functional DRD2 polymorphism in heroin-dependent cases and controls is limited to amphetaminedependent individuals. Addict. Biol.

Nigg, J.T., 2003. Response inhibition and disruptive behaviors: toward a multiprocess conception of etiological heterogeneity for ADHD combined type and conduct disorder early-onset type. Ann. N. Y. Acad. Sci. 1008, 170-182.

Oquendo, M., Brent, D., Birmaher, B., Greenhill, L., Kolko, D., Stanley, B., Zelazny, J., Burke, A., Firinciogullari, S., Ellis, S., Mann, J., 2005. Posttraumatic Stress Disorder Comorbid With Major Depression: factors mediating the association with suicidal behavior. Am. J. Psychiatry 162, 560-566.

Patton, J.H., Stanford, M.S., Barratt, E.S., 1995. Factor structure of the Barratt impulsiveness scale. J. Clin. Psychol. 51, 768-774.

Reise, S.P., Moore, T.M., Sabb, F.W., Brown, A.K., London, E.D., 2013. The Barratt Impulsiveness Scale-11: reassessment of its structure in a community sample. Psychol. Assess. 25, 631-642.

Rigotti, N.A., Moran, S.E., Wechsler, H., 2004. US college students' exposure to tobacco promotions: prevalence and association with tobacco use. Am. J. Public Health 94 (12).

Sanchez, J.A.O., 2015. Seguridad, Justicia y Paz. For the fourth consecutive year, San Pedro Sula is the most violent city in the world. Citizen's Council for Public Security and Criminal Justice. 〈http://www.seguridadjusticiaypaz.org.mx/bib lioteca/prensa/send/6-prensa/199-the-50-most-violent-cities-in-the-world2014).

Santos, C.T., Strina, A., Amorim, L.D., Genser, B., Assis, A.M.O., Prado, M.S., Barreto, M.L., 2011. Individual and contextual determinants of the duration of diarrhoeal episodes in preschool children: a longitudinal study in an urban setting. Epidemiol. Infect., 1-8.

Shin, S.H., Hong, H., Jeon, S.M., 2012. Personality and alcohol use: the role of impulsivity. Addict. Behav. 37, 102-107.

Soeiro-De-Souza, M.G., Stanford, M.S., Bio, D.S., Machado-Vieira, R., Moreno, R.A., 2013. Association of the COMT Met(1)(5)(8) allele with trait impulsivity in healthy young adults. Mol. Med. Rep. 7, 1067-1072.

Sonuga-Barke, E., 2002. Psychological heterogeneity in AD/HD: a dual pathway model of behavior and cognition. Behav. Brain Res. 130, 26-29.

Stanford, M.S., Mathias, C.W., Dougherty, D.M., Lake, S.L., Anderson, N.E., Patton, J. H., 2009. Fifty years of the Barratt Impulsiveness Scale: an update and review. Personal. Individ. Differ. 47, 385-395.

Swann, A.C., Bjork, J., Moeller, F.G., Dougherty, D.M., 2002. Two models of impulsivity: relationship to personality traits and psychopathology. Biol. Psychiatry 51, 988-994.

Swann, A.C., Steinberg, J.L., Lijffijt, M., Moeller, F.G., 2008. Impulsivity: differential relationship to depression and mania in bipolar disorder. J. Affect. Disord. 106, 241-248.

Swick, D., Honzel, N., Larsen, J., Ashley, V., 2013. Increased response variability as a marker of executive dysfunction in veterans with post-traumatic stress disorder. Neuropsychologia 14, 3033-3040.

Vasconcelos, A., Malloy-Diniz, L., Correa, H., 2012. Systematic review of psychometric proprieties of Barratt Impulsiveness Scale Version 11 (BIS-11) Clinical. Neuropsychiatry 9, 61-74.

von Diemen, L., Szobot, C.M., Kessler, F., Pechansky, F., 2007. Adaptation and construct validation of the Barratt Impulsiveness Scale (BIS 11) to Brazilian Portuguese for use in adolescents. Rev. Bras. Psiquiatr. 29, 153-156. 
Waiselfisz, J.J., 2012. Mapa da Violência 2012: A Cor dos Homicídios no Brasil Rio de Janeiro. In: CEBELA, F., SEPPIR/PR (Ed.). Rio de Janeiro, Brasília, Brazil.

Wechsler, H., Nelson, T.F., 2008. What we have learned from the Harvard School of Public Health College Alcohol Study: focusing attention on college student alcohol consumption and the environmental conditions that promote it. J. Stud. Alcohol Drugs 69 (4), 481-490.

Whiteside, S.P., Lynam, D.R., 2001. The Five Factor Model and impulsivity: using a structural model of personality to understand impulsivity. Personal. Individ. Differ. 30, 669-689.

Wilkins, K.C., Lang, A.J., Norman, S.B., 2011. Synthesis of the psychometric properties of the PTSD checklist (PCL) military, civilian, and specific versions. Depression Anxiety 28, 596-606.

Zuckerman, M., 1979. Sensation-seeking: Beyond the Optimal Level of Arousal. Erlbaum, Hillsdale, NJ. 